\title{
Clinical applications of mesenchymal stem cells in chronic lung diseases (Review)
}

\author{
KATERINA M. ANTONIOU ${ }^{1,2}$, KONSTANTINOS KARAGIANNIS ${ }^{1,2}$, ELIZA TSITOURA ${ }^{1}$, ELENI BIBAKI ${ }^{1,2}$, \\ ISMINI LASITHIOTAKI $^{1,2}$, ATHANASIA PROKLOU ${ }^{1,2}$, DEMETRIOS A. SPANDIDOS $^{3}$ and NIKOS TZANAKIS ${ }^{2}$ \\ ${ }^{1}$ Laboratory of Molecular and Cellular Pneumonology, Medical School, University of Crete; \\ ${ }^{2}$ Department of Thoracic Medicine, Interstitial Lung Disease Unit, University Hospital, University of Crete, \\ Heraklion 71110, ${ }^{3}$ Laboratory of Clinical Virology, Medical School, University of Crete, \\ Voutes, Heraklion 71003, Crete, Greece
}

Received January 4, 2018; Accepted February 12, 2018

DOI: $10.3892 /$ br.2018.1067

\begin{abstract}
Mesenchymal stem (stromal) cells (MSCs) are multipotent stromal cells that have the ability to modulate immune response to tissue injury and promote repair in vivo. The therapeutic potential of ex vivo expanded MSCs are currently under investigation for a variety of chronic and acute lung diseases. This review summarizes the encouraging results regarding the safety of MSCs administration from recent and current clinical trials for idiopathic pulmonary fibrosis, acute respiratory distress syndrome, and chronic obstructive pulmonary disease. It also reviews the early preliminary data extracted by the same trials regarding the efficacy of MSCs in the aforementioned lung diseases.
\end{abstract}

\section{Contents}

1. Introduction

2. Mesenchymal stem cells

3. MSCs and IPF

4. MSCS and ARDS

5. MSCs and COPD

6. Conclusion

\section{Introduction}

Mesenchymal stem (stromal) cells (MSCs) are multipotent stromal cells that can be isolated from bone marrow (BM), skeletal muscle, amniotic fluid and adipose tissue, among

Correspondence to: Dr Katerina M. Antoniou, Laboratory of Molecular and Cellular Pneumonology, Medical School, University of Crete, Heraklion 71110, Greece

E-mail:kantoniou@med.uoc.gr

Key words: mesenchymal stem cells, lung, idiopathic pulmonary fibrosis, acute respiratory distress syndrome, chronic obstructive pulmonary disease other tissues with a differentiation potential towards adipocytes, chondrocytes, and osteoblasts. Embryonic stem cells (ESCs) and adult stem cells are the two main categories of stem cells in human (1). Previous data suggested that stem cells may participate in tissue homeostasis and regeneration after injury and may originate either from the lung itself, termed resident progenitor cells (alveolar, endothelial and interstitial), or from distant sites such as blood, BM and adipose tissue, namely endothelial progenitor cells (EPCs) and MSCs, as previously mentioned (2-6). Adult-derived stem cells, such as MSCs have the ability to modulate immune response to tissue injury and promote repair in vivo, and have been suggested as an attractive therapeutic candidate for a variety of lung diseases, including idiopathic pulmonary fibrosis (IPF), acute respiratory distress syndrome (ARDS), and chronic obstructive pulmonary disease (COPD) (7). The main objective of this review is to highlight the main clinical studies of MSCs in humans regarding the application of stem cell as a novel treatment option in chronic lung diseases, including IPF, ARDS and COPD.

\section{Mesenchymal stem cells}

MSCs are multipotent cells characterized by their ability to differentiate into varying cell lines and to exert anti-proliferative, immunomodulatory, and anti-inflammatory effects. Recent studies have focused on the potential therapeutic applications of stem cells based on their multipotency, migratory ability, and immunoprivileged properties. MSCs have been extensively studied as a treatment option in various diseases, including severe graft versus host disease, pancreatic islet and renal glomerular repair in diabetes, ischemic acute renal failure, acute lung injury, and as cardiac function restorers after acute cardiac ischemic events (7-12).

Concerning the lungs, data from animal models have already shown the contribution of MSCs to tissue regeneration after elastase-induced emphysema, home to sites of asbestos-induced lung injury, and restoration of alveolar and lung fluid balance after endotoxin-induced acute lung injury $(13,14)$. Thus, the therapeutic potential of ex vivo expanded MSC is of great interest. 
Table I. Clinical trials of MSCs in respiratory diseases.

\begin{tabular}{|c|c|c|c|c|c|}
\hline Study (year) & Disease/ Condition & Cell Type & Delivery Route & Primary Endpoint & Refs. \\
\hline Ribeiro-Paes et al (2011) & Advanced COPD & BMMC & IV & Safety of SC infusion & $(36)$ \\
\hline Weiss et al (2013) & $\begin{array}{l}\text { Moderate to } \\
\text { severe COPD }\end{array}$ & BM-MSCs & IV & Safety of systemic MSC administration & \\
\hline Tzouvelekis et al (2013) & Mild to moderate IPF & ADSCs-SVF & EB & $\begin{array}{l}\text { Safety (incidence of treatment } \\
\text { emergent adverse events) }\end{array}$ & (19) \\
\hline Zheng et al (2014) & ARDS & AD-MSCs & IV & $\begin{array}{l}\text { Safety (possible adverse events after } \\
\text { systemic administration of AD-MSCs) }\end{array}$ & $(29)$ \\
\hline Chambers et al (2014) & Moderate IPF & PD-MSCs & IV & $\begin{array}{l}\text { Safety and feasibility of an infusion } \\
\text { of PD-MSCs }\end{array}$ & $(20)$ \\
\hline Wilson et al (2015) & $\begin{array}{l}\text { Moderate to } \\
\text { severe ARDS }\end{array}$ & BM-MSCs & IV & $\begin{array}{l}\text { Safety of BM MSCs intravenous } \\
\text { infusion }\end{array}$ & $(28)$ \\
\hline Baughman et al (2015) & $\begin{array}{l}\text { Advanced Pulmonary } \\
\text { Sarcoidosis }\end{array}$ & PD-MCs & IV & $\begin{array}{l}\text { Acute effect of cell therapy on } \\
\text { pulmonary artery pressure }\end{array}$ & $(37)$ \\
\hline Stolk et al (2016) & Severe emphysema & BM-MSCs & IV & $\begin{array}{l}\text { Safety and feasibility of } \\
\text { IV administration of BM-MScs }\end{array}$ & $(33)$ \\
\hline Glassberg et al (2017) & Mild to moderate IPF & BM-MSCs & IV & $\begin{array}{l}\text { Safety of a single infusion } \\
\text { of BM-MSCs }\end{array}$ & $(21)$ \\
\hline
\end{tabular}

BMMC, bone marrow mononuclear cells; IV, intravenously; SC, stem cell; BM-MSCs, bone marrow derived mesenchymal stem cells; ADSCs-SVF, adipose derived stem cells-stromal vascular factor; Endobronchially; AD-MSCs, adipose derived-mesenchymal stem cells; PD-MSCs, placenta derived-mesenchymal stem cells; PD-MCs, placenta derived-mesenchymal-like cells.

Tropea et al suggested that exposure to exogenous stem cells may induce the proliferation of resident endogenous progenitor cells in the lungs, thus contributing to tissue repair in a murine model (15). Moreover, bronchioloalveolar stem cells are capable of resisting bronchiolar and alveolar damage and proliferating during epithelial cell renewal (16). Jarvinen et al have shown anti-inflammatory and immunomodulatory properties of lung resident progenitor cells (17). Finally, Kajstura et al recently described a human lung resident stem cell line with the capacity for differentiation into bronchioles, alveoli, and pulmonary vasculature (5).

Despite all the aforementioned reports, a limited number of trials have been recorded in humans, owing to safety risks together with a limited knowledge of the mechanism of action of the various stem cell therapies that inevitably hinders the choice of optimal cell therapy.

\section{MSCs and IPF}

IPF is a lung disease of unknown origin characterized by loss of lung epithelial cells, parenchymal tissue remodeling, distortion of lung architecture, respiratory insufficiency and poor outcome despite the introduction of two novel therapeutic agents, pirfenidone and nintedanib (18). The pathogenesis of IPF is characterized by epithelial cell injury, interstitial inflammation, extracellular matrix collagen deposition, and eventual loss of function. MSCs are home to sites of injury, inhibit inflammation, and contribute to epithelial tissue repair. Thus, their use has been suggested as a potential therapy for the treatment of IPF (19).

A recent single center, open-label phase $1 \mathrm{~b}$ study by Tzouvelekis et al assessed the safety profile of the endobron- chial administration of adipose derived stromal cells-stromal vascular fraction (ADSCs-SVF; $n=14$ ), in patients with mild to moderate IPF. Stability in functional and exercise tolerance was found in the majority of the studied population $(86 \%)$ 1 year after follow-up. There were no reported serious or clinically relevant side effects in the 24-month follow-up period after the first infusion (20) (Table I).

In another recent single center phase 1 study, by Chambers et al patients with IPF received intravenous placenta-derived hMSCs $(\mathrm{n}=8)$. In this non-randomized, dose escalation phase $1 \mathrm{~b}$ trial, patients with moderately severe IPF [diffusing capacity for carbon monoxide (DLCO) $\geq 25 \%$ and forced vital capacity $(\mathrm{FVC}) \geq 50 \%$ ] received either $1 \times 10^{6}(\mathrm{n}=4)$ or $2 \times 10^{6}(\mathrm{n}=4)$ unrelated-donor, placenta-derived $\mathrm{MSC} / \mathrm{kg}$ via a peripheral vein and were followed for 6 months with lung function (FVC and DLCO), 6-min walk distance (6MWD) and chest computed tomography. Most adverse events (AEs) were mild and self-limiting and no deaths were reported (21) (Table I).

Recent results from the AETHER study, published by Glassberg et al (22), constituted the first human trial designed to evaluate the safety of BM-derived human allogeneic MSCs (BM-hMSCs) in patients with mild to moderate IPF. In this non-randomised, non-placebo single-centre clinical trial, BM-MSCs from two men were cultured and subsequently administered as a single intravenous infusion to nine patients with mild to moderate IPF. No treatment -related serious AEs were reported with infusions up to $2 \times 10^{8}$ cells over a 60 -week follow-up period. Two non-study related deaths were recorded. Non-serious AEs unrelated to treatment were reported in most patients $(78 \%)$, most frequently bronchitis and the common cold. Mean absolute declines of $3.0 \%$ predicted FVC and 
$5.4 \%$ predicted DLCO were described 60 weeks after infusion, which are below the internationally accepted thresholds representing disease progression (22) (Table I).

\section{MSCS and ARDS}

ARDS is characterized by acute hypoxemic respiratory failure that develops primarily from an increase in lung endothelial and epithelial permeability. ARDS develops in response to multiple predisposing factors, including pneumonia, systemic sepsis, as well as major surgery or multiple trauma, with pulmonary and extrapulmonary sepsis accounting for $75 \%$ of all predisposing causes of ARDS. The pathologic hallmark of ARDS consists of diffuse alveolar damage, with injury to both the lung endothelium and epithelium $(23,24)$.

Preclinical data support the therapeutic potential of several stem cell types for ARDS. ESCs have been differentiated to produce functional airway epithelium, while MSCs derived from ESCs attenuate murine endotoxin- and bleomycin-induced lung injury $(25,26)$. Regarding EPCs, which comprise circulating progenitor cells involved in the repair of endothelial cells, data from several preclinical studies have shown encouraging results in cases of endotoxin lung injury $(27,28)$.

Recently, a phase $1 \mathrm{~b}$ dose escalation study, was published by Wilson et al, with three doses of human BM-MSCs $(1,5$, and $106 \mathrm{MSCs} / \mathrm{kg}$ ideal body weight) given intravenously over $1 \mathrm{~h}$ in 9 patients with moderate to severe ARDS [defined as a $\mathrm{PaO}_{2} / \mathrm{FiO}_{2}<200 \mathrm{mmHg}$ ventilated with at least $8 \mathrm{cmH}_{2} \mathrm{O}$ positive end-expiratory pressure (NCT01775774)] (29). This research group is now conducting a randomized, blinded phase 2a safety trial in 60 patients [ 40 treated with MSCs at $106 \mathrm{MSCs} / \mathrm{kg}$ ideal body weight and 20 with plasmalyte placebo (NCT02097641)] (Table I).

Zheng et al assessed the safety profile of MSCs with the administration of a low dose of 1 million adipose-derived $\mathrm{hMSCs} / \mathrm{kg}$ in 12 adult patients meeting the Berlin definition of ARDS. Acute lung injury biomarkers, including IL-6, IL-8 and surfactant protein D (SP-D), were examined to determine the effects of MSCs on lung injury and inflammation. No infusion toxicities or serious AEs related to MSCs administration were reported, although the clinical effect was weak (30) (Table I).

\section{MSCs and COPD}

COPD is the fourth leading cause of death worldwide and a major cause of chronic morbidity and mortality. Experimental models have aimed to investigate the pathophysiology of pulmonary emphysema as one of the main expressions of COPD and to identify new treatment approaches, as the current treatment aims are supportive and not curative. Nevertheless, the first animal model of rodent MSC administration in COPD has been published $(31,32)$.

Weiss et al reported a phase II, multicenter, randomized, double-blind placebo-controlled study, to evaluate the safety and efficacy of intravenous allogeneic MSCs for the treatment of moderate to severe COPD (33). Thirty COPD patients received four monthly infusions of MSCs (100x106 cells/infusion) with a 2-year follow-up. The primary endpoint was safety, assessed by occurrence of AEs, electrocardiography
(ECG), and COPD exacerbations. The results demonstrated that the administration of MSCs in patients with moderate to severe COPD appears to be safe, with no AEs or an increased rate of exacerbations recorded during the study. However, no significant clinical improvement was detected.

Currently, the only treatment available for severe emphysema is lung volume reduction surgery (LVRS). Stolk et al reported a phase I, non-randomized, non-blinded, prospective study, regarding the safety and feasibility of administering BM-MSCs before and after LVRS for severe emphysema (34). Two BM-MSCs infusions in 10 patients 1 week apart, 4 and 3 weeks prior to the second LVRS, respectively were performed. No AEs related to the infusions were observed in the first $48 \mathrm{~h}$ and at 3 weeks after the second infusion, or the day before the second LVRS.

Furthermore, a phase I, non-randomized, open-label study has recently been completed, regarding the safety evaluation of MSC administration in patients with severe heterogeneous emphysema and placement of one-way endobronchial valve (35). In addition, that study investigated whether this treatment modality modulates other markers of inflammatory response and remodeling. Five patients received BM-MSC immediately preceding insertion of one-way endobronchial valves by bronchoscopy. No AEs or lung deficits during the procedure and/or follow-up were reported.

Currently, several clinical trials are ongoing worldwide regarding the safety and efficacy of stem cell based therapies in COPD including ASDC, BM-MSC, and plerixa for mobilization of CD117 stem cells to peripheral blood. The current cell dosage has not elicited a long-term therapeutic effect. Further evaluation of efficacy and safety of systemic and local administration of autologous or allogeneic MSCs in the treatment of COPD is needed.

\section{Conclusion}

In conclusion, recent clinical trials of autologous or allogeneic MSCs administration in patients with various respiratory diseases provide adequate evidence for the safety of use of MSCs in those groups of patients. Consequently, phase II human trials including different sources, doses and routes of administration are the next step in the assessment of the efficacy of MSCs in respiratory diseases.

\section{Acknowledgements}

Not applicable.

\section{Funding}

No funding was received.

\section{Availability of data and materials}

Not applicable.

\section{Authors' contributions}

All authors have contibuted to the conception and design of the work, revising it for important intellectual content. The final 
version of the manuscript has been read and approved by all authors.

\section{Ethics approval and consent to participate}

Not applicable.

\section{Consent for publication}

Not applicable.

\section{Competing interests}

The authors declare that they have no competing interests. Demetrios A. Spandidos is the Editor-in-Chief for the journal, but had no personal involvement in the reviewing process, or any influence in terms of adjudicating on the fnal decision, for this article.

\section{Authors' information (optional)}

Not applicable.

\section{References}

1. Fuchs E and Segre JA: Stem cells: A new lease on life. Cell 100: $143-155,2000$

2. Gomperts BN and Strieter RM: Stem cells and chronic lung disease. Annu Rev Med 58: 285-298, 2007.

3. Rankin S: Mesenchymal stem cells. Thorax 67: 565-566, 2012.

4. Crystal RG, Randell SH, Engelhardt JF, Voynow J and Sunday ME: Airway epithelial cells: Current concepts and challenges. Proc Am Thorac Soc 5: 772-777, 2008.

5. Kajstura J, Rota M, Hall SR, Hosoda T, D'Amario D, Sanada F Zheng H, Ogórek B, Rondon-Clavo C, Ferreira-Martins J, et al: Evidence for human lung stem cells. N Engl J Med 364: 1795-1806, 2011.

6. Rankin SM: Chemokines and adult bone marrow stem cells. Immunol Lett 145: 47-54, 2012.

7. Gupta N, Su X, Popov B, Lee JW, Serikov V and Matthay MA: Intrapulmonary delivery of bone marrow-derived mesenchymal stem cells improves survival and attenuates endotoxin-induced acute lung injury in mice. J Immunol 179: 1855-1863, 2007.

8. Iyer SS and Rojas M: Anti-inflammatory effects of mesenchymal stem cells: Novel concept for future therapies. Expert Opin Biol Ther 8: 569-581, 2008.

9. Krampera M, Pasini A, Pizzolo G, Cosmi L, Romagnani S and Annunziato F: Regenerative and immunomodulatory potential of mesenchymal stem cells. Curr Opin Pharmacol 6: 435-441, 2006.

10. Weiss DJ, Kolls JK, Ortiz LA, Panoskaltsis-Mortari A and Prockop DJ: Stem cells and cell therapies in lung biology and lung diseases. Proc Am Thorac Soc 5: 637-667, 2008.

11. Schuleri KH, Feigenbaum GS, Centola M, Weiss ES, Zimmet JM, Turney J, Kellner J, Zviman MM, Hatzistergos KE, Detrick B, et al: Autologous mesenchymal stem cells produce reverse remodelling in chronic ischaemic cardiomyopathy. Eur Heart J 30: 2722-2732, 2009

12. Miyahara Y, Nagaya N, Kataoka M, Yanagawa B, Tanaka K, Hao H, Ishino K, Ishida H, Shimizu T, Kangawa K, et al: Monolayered mesenchymal stem cells repair scarred myocardium after myocardial infarction. Nat Med 12: 459-465, 2006.

13. Ishizawa K, Kubo H, Yamada M, Kobayashi S, Numasaki M, Ueda S, Suzuki T and Sasaki H: Bone marrow-derived cells contribute to lung regeneration after elastase-induced pulmonary emphysema. FEBS Lett 556: 249-252, 2004.

14. Spees JL, Pociask DA, Sullivan DE, Whitney MJ, Lasky JA, Prockop DJ and Brody AR: Engraftment of bone marrow progenitor cells in a rat model of asbestos-induced pulmonary fibrosis. Am J Respir Crit Care Med 176: 385-394, 2007.
15. Tropea KA, Leder E, Aslam M, Lau AN, Raiser DM, Lee JH, Balasubramaniam V, Fredenburgh LE, Alex Mitsialis S, Kourembanas S, et al: Bronchioalveolar stem cells increase after mesenchymal stromal cell treatment in a mouse model of bronchopulmonary dysplasia. Am J Physiol Lung Cell Mol Physiol 302: L829-L837, 2012.

16. Kim CF, Jackson EL, Woolfenden AE, Lawrence S, Babar I, Vogel S, Crowley D, Bronson RT and Jacks T: Identification of bronchioalveolar stem cells in normal lung and lung cancer. Cell 121: 823-835, 2005.

17. Jarvinen L, Badri L, Wettlaufer S, Ohtsuka T, Standiford TJ, Toews GB, Pinsky DJ, Peters-Golden M and Lama VN: Lung resident mesenchymal stem cells isolated from human lung allografts inhibit $\mathrm{T}$ cell proliferation via a soluble mediator. J Immunol 181: 4389-4396, 2008.

18. Toonkel RL, Hare JM, Matthay MA and Glassberg MK; Potential for Clinical Testing: Mesenchymal stem cells and idiopathic pulmonary fibrosis. Potential for clinical testing. Am J Respir Crit Care Med 188: 133-140, 2013.

19. Tzouvelekis A, Paspaliaris V, Koliakos G, Ntolios P, Bouros E, Oikonomou A, Zissimopoulos A, Boussios N, Dardzinski B, Gritzalis $\mathrm{D}$, et al: A prospective, non-randomized, no placebo-controlled, phase Ib clinical trial to study the safety of the adipose derived stromal cells-stromal vascular fraction in idiopathic pulmonary fibrosis. J Transl Med 11: 171, 2013.

20. Chambers DC, Enever D, Ilic N, Sparks L, Whitelaw K, Ayres J, Yerkovich ST, Khalil D, Atkinson KM and Hopkins PM: A phase $1 \mathrm{~b}$ study of placenta-derived mesenchymal stromal cells in patients with idiopathic pulmonary fibrosis. Respirology 19: 1013-1018, 2014

21. Glassberg MK, Minkiewicz J, Toonkel RL, Simonet ES, Rubio GA, DiFede D, Shafazand S, Khan A, Pujol MV, LaRussa VF, et al: Allogeneic Human Mesenchymal Stem Cells in Patients With Idiopathic Pulmonary Fibrosis via Intravenous Delivery (AETHER): A Phase I Safety Clinical Trial. Chest 151: 971-981, 2017.

22. Ranieri VM, Rubenfeld GD, Thompson BT, Ferguson ND, Caldwell E, Fan E, Camporota L and Slutsky AS; ARDS Definition Task Force: Acute respiratory distress syndrome: The Berlin Definition. JAMA 307: 2526-2533, 2012.

23. Matthay MA, Ware LB and Zimmerman GA: The acute respiratory distress syndrome. J Clin Invest 122: 2731-2740, 2012.

24. McIntyre BA, Alev C, Mechael R, Salci KR, Lee JB, Fiebig-Comyn A, Guezguez B, Wu Y, Sheng G and Bhatia M: Expansive generation of functional airway epithelium from human embryonic stem cells. Stem Cells Transl Med 3: 7-17, 2014.

25. Hao Q, Zhu YG, Monsel A, Gennai S, Lee T, Xu F and Lee JW: Study of Bone Marrow and Embryonic Stem Cell-Derived Human Mesenchymal Stem Cells for Treatment of Escherichia coli Endotoxin-Induced Acute Lung Injury in Mice. Stem Cells Transl Med 4: 832-840, 2015.

26. Rafat N, Dacho C, Kowanetz G, Betzen C, Tönshoff B, Yard B and Beck G: Bone marrow-derived progenitor cells attenuate inflammation in lipopolysaccharide-induced acute respiratory distress syndrome. BMC Res Notes 7: 613, 2014.

27. Yin X, Liang Z, Yun Y and Pei L: Intravenous Transplantation of BMP2-Transduced Endothelial Progenitor Cells Attenuates Lipopolysaccharide-Induced Acute Lung Injury in Rats. Cell Physiol Biochem 35: 2149-2158, 2015.

28. Wilson JG, Liu KD, Zhuo H, Caballero L, McMillan M, Fang X, Cosgrove K, Vojnik R, Calfee CS, Lee JW, et al: Mesenchymal stem (stromal) cells for treatment of ARDS: A phase 1 clinical trial. Lancet Respir Med 3: 24-32, 2015.

29. Zheng G, Huang L, Tong H, Shu Q, Hu Y, Ge M, Deng K, Zhang L, Zou B, Cheng B, et al: Treatment of acute respiratory distress syndrome with allogeneic adipose-derived mesenchymal stem cells: A randomized, placebo-controlled pilot study. Respir Res 15: 39, 2014

30. Shigemura N, Okumura M, Mizuno S, Imanishi Y, Matsuyama A, Shiono H, Nakamura T and Sawa Y: Lung tissue engineering technique with adipose stromal cells improves surgical outcome for pulmonary emphysema. Am J Respir Crit Care Med 174: 1199-1205, 2006

31. Zhen G, Xue Z, Zhao J, Gu N, Tang Z, Xu Y and Zhang Z: Mesenchymal stem cell transplantation increases expression of vascular endothelial growth factor in papain-induced emphysematous lungs and inhibits apoptosis of lung cells. Cytotherapy 12: 605-614, 2010. 
32. Weiss DJ, Casaburi R, Flannery R, LeRoux-Williams M and Tashkin DP: A placebo-controlled, randomized trial of mesenchymal stem cells in COPD. Chest 143: 1590-1598, 2013.

33. Stolk J, Broekman W, Mauad T, Zwaginga JJ, Roelofs H, Fibbe WE, Oostendorp J, Bajema I, Versteegh MI, Taube C, et al: A phase I study for intravenous autologous mesenchymal stromal cell administration to patients with severe emphysema. QJM 109: 331-336, 2016

34. U.S. National Library of Medicine: Safety Study of Bonemarrow Derived Mesenchymal Stromal Cells Associated With Endobronchial Valves in Emphysema. ClinicalTrials.gov Identifier: NCT01872624. https://clinicaltrials.gov/ct2/show/ record/NCT01872624. Last updated posted: March 25, 2015. 3

35. ClinicalTrials.gov Identifier: NCT01872624. Safety Study of Bone-marrow Derived Mesenchymal Stromal Cells Associated With Endobronchial Valves in Emphysema.
36. Ribeiro-Paes JT, Bilaqui A, Greco OT, Ruiz MA, Marcelino MY, Stessuk T, de Faria C and Lago MR: Unicentric study of cell therapy in chronic obstructive pulmonary disease/pulmonary emphysema. Int J Chron Obstruct Pulmon Dis: 6: 63-71, 2011.

37. Baughman RP1, Culver DA, Jankovi V, Fischkoff S, Brockway G and Lower EE: Placenta-derived mesenchymal-like cells (PDA-001) as therapy for chronic pulmonary sarcoidosis: A phase 1 study. Sarcoidosis Vasc Diffuse Lung Dis 32: 106-14, 2015.

(†) $\Theta$ This work is licensed under a Creative Commons Attribution-NonCommercial-NoDerivatives 4.0 International (CC BY-NC-ND 4.0) License. 